politica, 38. årg. nr. 3 2006, 264-279

\title{
Mette Skak
}

\section{Ruslands globaliseringsstrategi}

\begin{abstract}
Blandt BRIK-landene (Brasilien, Rusland, Indien, Kina) udgør Rusland et særtilfælde især grundet den lange sovjetiske isolationsfase. Sovjetkommunismens sammenbrud åbner for, at Rusland omsider kan blive inddraget i verdenspolitikkens og - $\varnothing \mathrm{ko}-$ nomiens hovedstrøm, i dag kaldet globaliseringen. De russiske samfundsforskeres syn på globaliseringen er imidlertid ofte defensivt eller konspirationsteoretisk, og elitens globaliseringsstrategi tilsvarende stats- og kontrolfikseret (jf. sloganet "det suveræne demokrati”). Resultatet er en udpræget korporatisme, hvilket både russiske og vestlige samfundsforskere anser for en af globaliseringens kerneudfordringer. Men der er også lyspunkter i Rusland såsom en langt større selverkendelse på områder som Ruslands demografiske deroute. Det russiske civilsamfund er svagt, men ikke uberørt af de muligheder, som globaliseringen skaber på græsrodsplan selv i rigets fjerneste afkroge.
\end{abstract}

"... for all the talk about the imperatives of globalization and the pressure to adapt to those imperatives, it is the continued variation of development trajectories that is most striking. [...] powerful external pressures for change have come up against very deep-rooted sets of domestic social, political and economic structures and very distinctive national traditions, leading to developmental trajectories that continue to vary significantly" (Hurrell, 2006: 17).

Som det fremgår af Andrew Hurrells betragtninger, skal man vare sig for at generalisere om globaliseringen, hvor selvmodsigende det end måtte lyde. Når emnet for den konkrete globaliseringsstudie er Rusland, som tilfældet er her, tæller hans indsigt dobbelt. Rusland udgør simpelthen the outlier, altså særtilfældet blandt de BRIK-lande ${ }^{1}$, som mange mener samlet bør gøres til genstand for særskilt analyse, fordi netop de udgør nogle afgørende statslige globaliseringsaktører og markeder (O'Neill, 2001, 2006; Wilson og Purushothaman, 2003; Hurrell, 2006; MacFarlane, 2006). Emnet for det følgende er derfor Rusland som globaliseringsaktør og den russiske strategi over for globaliseringen, dvs. en analyse af dels det russiske syn på globaliseringen, dels den russiske regerings globaliseringspraksis. Det suppleres med stof om udviklingen på civilsamfundsniveau og de særlige udfordringer, Rusland står over for grundet landets enorme udstrækning og delvis arktiske klima.

Det, der gør Rusland speciel, er landets abnormt lange afkobling fra hovedstrømmen i international politik og økonomi i det 20. århundrede pga. bolsjevikkernes, navnlig Stalins valg af isolation, militarisme og selvforsyning som udviklingsstrategi (Skak, 1993, 1996: 76-100; van Ree, 2002: 96ff.). Afkoblingen forværrede det udviklingsefterslæb, som allerede det zaristiske Rusland var havnet i, tydeliggjort med nederlagene i Krimkrigen og den Russisk-japanske krig (Skak, 1993). Først da Mikhail Gorbatjov kom til magten i 1985, begyndte det egentlige opgør med Stalins totalitære afsondring - indtil da havde sovjetborgeren haft udrejseforbud, bønderne var reelt stavnsbundne, og økonomien forkrøblet af 
militærets fortrinsstilling. Selve omstillingen (perestrojka) gav en uundgåelig nedtur i magt og levevilkår; den og udviklingen forud gør Rusland til en afviger blandt BRIK-landene. ${ }^{2}$ Perioden siden det fejlslagne kupfors $\varnothing g$ i august 1991 har været turbulent, derfor befinder Rusland sig langt fra den selvsikre globalisering, som man ser i lande som Kina og Indien (se Clemens Stubbe Østergaards og Jørgen Dige Pedersens artikler i dette nummer).

Følgelig må Ruslands globalisering - eller problemer med samme (Larsson, 2005) - forstås på baggrund af landets tragiske nyere historie samt indskrækningen i dets storpolitiske handlerum og ikke kun ud fra almen globaliseringsteori (fx Scholte, 2005; Friedman, 2005). Det var Ruslands første udenrigsminister, Andrej Kozyrev, inde på, da han i 1990 afstak landets udenrigspolitiske prioriteter som et system af koncentriske cirkler med de post-sovjetiske lande som inderkredsen, dernæst det Euro-atlantiske område og Nordøstasien som sekundær interesse med resten af verden helt ude i yderkredsen af det russiske synsfelt (Skak, 1996: 144). Ikke desto mindre er Rusland her i præsident Vladimir V. Putins anden præsidentperiode præget af en ny selvfølelse, næsten arrogance som under dette års "gaskrig" i EU-Ruslandforholdet.

Analysen falder i to dele svarende til en simpel opdeling af stoffet i "ord" og "handling". Dette koncept er valgt for at kunne sammenholde den russiske globaliseringsdiskurs med den statslige globaliseringspraksis med de faldgruber, den rummer. Formelt tager artiklens praksisanalyse afsæt i et bredt globaliseringsbegreb, der understreger bredden i den udfordring, som tidligere lukkede samfund som det russiske står over for. Men artikelformen levner ikke plads til en fuldt udfoldet empirisk analyse, derfor lægges vægten på Ruslands politiske $ø$ konomi, dvs. forholdet mellem stat, marked og civilsamfund som vel nok globaliseringens kerneproblematik. Det suppleres med den overordnede retlige dimension af globaliseringen, som mange politologer overser, samt mere sporadisk stof om fx kulturelle og lokale aspekter af globaliseringen i Rusland. Mine oversættelser fra russisk er markeret med (MS).

\section{Den russiske globaliseringsdiskurs}

Globalisering handler om, at samkvemmet mellem aktører kloden rundt bliver mere intenst og uhæmmet af tid og rum grundet teknologiske gennembrud. Det indebærer en modifikation af statens kontrol med interaktionen inden for dens territorium, altså en udfordring af dens suverænitet. Den kendsgerning udgør den essentielle globaliseringsproblematik set med russiske øjne (Rozanova, 2003; Toft Sørensen, 2005). Således skriver historikeren Nikolaj A. Kosolapov (2005: 11): "globaliseringen bliver irreversibel, den forandrer selve staten som institution i samfundslivet og verdenssamfundet" (MS). Denne indfaldsvinkel, der genfindes hos russiske beslutningstagere, vidner om, at Rusland i sin selvopfattelse og tilgang til international politik udgør det, som Georg Sørensen (1998) og Robert Cooper (2004) kalder en moderne aktør, dvs. en "westfalsk" stat, der anser suveræniteten for en absolut værdi (hvorimod EU er en post-moderne aktør, der hviler på princippet om suverænitetsafgivelse). Følgelig er den russiske regeringselites overordnede løsning på globaliseringens udfordringer det såkaldte 
suveræne demokrati (suverennaja demokratija), ${ }^{3}$ der nu fortrænger sloganet "det styrbare demokrati" (upravljaemaja demokratija).

Hvad er da "suverænt demokrati"? Her vil jeg citere Vjateslav A. Nikonov, formanden for Klub-934 og dermed en af ophavsmændene til Ruslands udenrigsog indenrigspolitik. Umiddelbart betoner han begge begrebets elementer: Dels sikrer den fleksibilitet, som demokrati og frihed indebærer, evnen til at møde det postindustrielle samfunds udfordringer, "hvor myriader af selvstændigt agerende subjekter bestandigt må reagere på myriader af vidt forskellige impulser uden at afvente godkendelse fra nogen alvidende instans" (Nikonov, 2006/MS). Dels sikrer suveræniteten "statens uafhængighed udadtil og fortrinsstilling i indre anliggender". Følgelig skal det suveræne demokrati forstås som "ethvert folks ret til udvikling fri fra indblanding udefra samt folkerettens primat" (Nikonov, 2006/ MS). Det lyder tilforladeligt, men Nikonov afviser her integration med EU og NATO som optioner for Rusland: "en integration, der ophæver suveræniteten, er en ren blindgyde for os" (nam nekuda, Nikonov, 2006/MS). I stedet må Rusland afstive sig "gennem sit permanente medlemskab af FN's Sikkerhedsråd samt ved at være den eneste magt, der spænder fra Europa til Stillehavet; som supermagt på områderne energi, kernekraft, rumfart, råstofudvinding med det enorme bidrag til verdenscivilisationens udvikling gennem det seneste årtusinde, det altsammen har indebåret" (Nikonov, 2006/MS). Selvfølelsen fejler ikke noget, men det defensive og selvmodsigende i "suverænt demokrati" springer i øjnene. Ja, jf. nedenfor må man nok konkludere, at russiske beslutningstagere i praksis vil stå mere vagt om suveræniteten end demokratiet og friheden i konflikter mellem hensynet til individet og staten.

Det suveræne demokrati blev gjort til regeringsdoktrin af Putins "chefstrateg" Vladislav Ju. Surkov - vicechefen for præsidentforvaltningen, dvs. Ruslands reelle regering - i en tale holdt på et møde i interesseorganisationen Delovaja Rossija (ErhvervsRusland) 11.07.05. Her sagde han: "Vores projekt er banalt. Jeg ville kort og godt kalde det 'suverænt demokrati'. Jeg hører ofte, at demokrati er vigtigere end suverænitet. Det anerkender vi ikke. Begge må til”" (Surkov, 2005a), tilføjede han ganske vist. Men alligevel er det en lige så umage konstruktion som Surkovs forrige påhit, "det styrbare demokrati". På regeringsniveau er "suverænitet" blevet kodeordet i den faktiske globaliseringsdiskurs, som da Surkov varmede op til Putins årlige tale om Føderationen ved at pege på den trussel mod Ruslands suverænitet, der ligger i Vestens brug af "orange teknologier" - en hentydning til Vestens støtte til Ukraines orange revolution heri så han en fare for Ruslands "blide absorbering" (Surkov, 2006). Surkov er formand for regeringspartiet Jedinaja Rossija (Det Forende Rusland) og bekender sig åbenlyst til konservatismen med dens konnotationer af kollektivisme og nostalgi for fortiden, tildels sovjetfortiden (Surkov, 2005b). Kritikerne mener, at Putins chefideologer skamrider begreberne demokrati og suverænitet - at Kreml's "tredje vej" er useriøs og blot skal sikre grebet om magten (Novoprudskij, 2005). Nikonov er mere nuanceret end Surkov (2005a, 2006), der jo anslăr konspirationsteoretiske strenge i sin udlægning af det suveræne demokrati. Men facit er en nationalt-konservativ platform som Putin-ledelsens svar på globalise- 
ringen, herunder Vestens pres for åbenhed - politisk og økonomisk (jf. Yasmann, 2006).

Hvad angår debatten blandt russiske akademiske globaliseringseksperter, har sociologen Julia Rozanova (2003) fra Gorbatjov-stiftelsens globaliseringsprojekt lavet en glimrende diskursanalyse, der er kilde for det følgende, hvor intet andet er anført. Også hun indleder med at fremhæve den status, begrebet national suverænitet har som politisk svar på globaliseringens udfordringer blandt samfundsforskerne. Enkelte er på linje med Paul Hirst og Grahame Thompson (2001) i deres afdramatisering af nutidens angivelige globalisering. Men det negative og truende ved globaliseringen optager mange, fx Boris Kagarlitskij, der ser globalisering som kun et skalkeskjul for multinationale virksomheders samt USA's dominans. ${ }^{5}$ Ganske sværmerisk foreslår nogle, at Rusland sætter sig i spidsen for klodens tabere i globaliseringsprocessen. Mere på linje med vestlig forskning i governance og multilateralisme som svaret på globalisering er Mikhail I. Ilyin, der ser nye muligheder for højnet politisk deltagelse og har blik for den myndiggørelse (empowerment) af individet og civilsamfundet, som globaliseringen kan bane vej for. Desværre ser denne erkendelse ikke rigtig ud til at interessere den russiske politiske elite, der som ovenfor vist frygter den manglende kontrol over civilsamfundet (jf. fjendebilledet "de orange teknologier").

Nok så tankevækkende er Rozanovas (2003: 657ff.) præsentation af Krasin, Galkin og Medvedjevs pointer om globaliseringens dilemmaer. Dels mener de, at globaliseringen udløser en ny krise for demokratiet kloden over, og i Rusland er såvel befolkning som elite tilbøjelig til at foretrække autoritære "løsninger" frem for demokratiets uvished. Men førstnævnte er ingen option, det har været forsøgt med tragiske følger; derfor kan Rusland kun overleve globaliseringen via et stærkt demokrati. Dels er der dilemmaet mellem civile og korporative kanaler for interessevaretagelse, hvor Krasin et al. frygter, at ikke bare Rusland, men hele kloden er på vej ind $\mathrm{i}$ et korporatistisk årtusind som følge af svage civilsamfund, fraværet af uafhængige fagforeninger og tendensen til, at oligarkier samler den $\emptyset$ konomiske magt ikke mindst $\mathrm{i}$ det råvareproducerende Rusland. Som Rozanova bemærker, genfindes denne advarsel mod globaliseringens "iboende" korporatisme hos Stopford og Strange (1991) samt Lehmbruch og Schmitter (1982: 266-267).

Problemet i korporatisme - defineret som funktionelle interessers repræsentation - er den tilsidesættelse af folkevalgte, parlamentariske kanaler, som korporatisme generelt indebærer. Det fører ofte til magtmisbrug, da ikke-folkevalgte fora ikke stilles til regnskab over for samfundet som helhed, ergo berøves samfundet herved en central mekanisme til at korrigere sine fejl. Det gælder uanset, at den nordiske pluralistiske variant af korporatisme - trepartsforhandlinger osv. - i praksis har afstivet demokratiet ved at dæmpe modsætningerne i samfundet gennem fine kompromiser. De fleste forbinder nok privatkapitalistiske "røverbaroner" med faren for korporatisme i en russisk sammenhæng. Men her vil jeg minde om den oplagte fare for uigennemskuelig magtudøvelse og lyssky manøvrer fra bureaukraters side, som ligger i de aktuelle tendenser til renationalisering af produktionsselskaber jf. nedenfor - statslig bureaukrat-korporatisme kunne 
man kalde det. ${ }^{6}$ Derudover minder Krasin et al.s opfattelse af civilsamfundet som det sunde anker for globaliseringen om Peter Evans' (1997) pointe om statens styrkelse gennem indlejring i det omgivende samfund.

Ovenstående vue over den russiske globaliseringsdebat giver indtryk af et defensivt og pessimistisk syn på globaliseringen, men der findes enkelte undtagelser. Dmitrij Trenins (2002) analyse af Ruslands reelle optioner under globaliseringens vilkår bør nævnes. Det er et bidrag, der ser Rusland som skæringspunktet mellem modernitet (: nutidens russiske politiske univers) og post-modernitet (: globaliseringen generelt og EU i særdeleshed). Trenin afviser de russiske geopolitikeres vision om Eurasien, dvs. Rusland som brobygger mellem verdensdelene; i stedet gælder det om at indhente det forsømte og forankre Rusland i Europa. Jekaterinburg- økonomen S. Mitsek (2002) stiller retorisk spørgsmålet: ”Bør Rusland frygte globaliseringen?" og besvarer det benægtende ved at henvise til den beskedne importkvote - 7,8 pct. i 1999 altså svarende til mønstret i andre stormagter, hvorimod Polens og navnlig Ungarns importkvoter er langt højere. Han ønsker mere globalisering, da den kan fremme udenlandske investeringer, som Rusland har brug for for at højne levestandarden og opbygge en alsidig $\emptyset$ konomi. Målt på investeringer pr. indbygger halter Rusland imidlertid bagud for den $\varnothing$ vrige verden, herunder BRIK-landene med sine kun 115\$ i 1999 (tallet for Brasilien var da 965\$, 340\$ for Kina, dog kun $16 \$$ for Indien; Mitsek, 2002).

Ligesom Hirst og Thompson (2001) ser Mitsek globaliseringen som en proces, der begyndte i årene 1870-1913. 1913 er tilfædigvis referenceåret for Ruslands egen industrialisering, ganske vist under zarismens krasse ulighed. Mitsek peger på det indiskutable løft i velfærd, som EU-landene har oplevet trods verdenskrigenes afbræk, og den tilsvarende fremgang i åbne økonomier som Ungarn, Malaysia, Kina, Chile og Sydkorea. Han erkender, at globaliseringen højner uligheden mellem eksportbrancher og hjemmemarkedssektorer også i Rusland, hvor ansatte i fx oliebranchen tjener adskillige gange mere end landsgennemsnittet. Modsat ligger letindustri og landbrug på omkring halvdelen af gennemsnitslønnen. Men Mitsek mener, at Ruslands anti-globalister, herunder erhvervslivet gør ondt værre ved deres modstand mod landets verdensmarkedsdeltagelse. Han argumenterer med det paradoksale udfald af den krise, der i august 1998 ramte Rusland som følge af krisen i Asien året før, altså en krise udløst af globaliseringen. Rublens styrtdyk kom som sendt fra himlen med hensyn til at skabe makroøkonomisk stabilitet og tæmme inflationen - hvortil jeg vil føje, at det også var en saltvandsindsprøjtning for det spirende russiske private erhvervsliv, der blomstrede op som følge af prishoppet på importvarer. Mitsek konkluderer, at Rusland skal stille krav til udenlandske investorer om at højne arbejdskraftens kvalifikationer og genroprette miljøet, ligesom myndighederne skal regulere indvandringen af arbejdskraft - man skal simpelthen gå offensivt ind i globaliseringen.

\section{Den statslige russiske globaliseringspraksis og andre facetter af globaliseringen}

Mit eget syn på globaliseringen er åbent, ikke på forhånd globaliseringsfjendtligt. ${ }^{7}$ Ikke mindst, når analysens genstand som her er et land med en totalitær fortid, er 
det vigtigt at have $\varnothing j$ je for den frisættelse af det enkelte menneske, som globaliseringen også åbner for (jf. Rosenau, 1990). Globalisering er unægtelig et sammensat fænomen, ikke bare godt eller skidt. Men nøglen til at opnå globaliseringens positive følgevirkninger er uden tvivl et åbent samfund i Karl Poppers (2001) forstand - sagt mere direkte: et stærkt og levende demokrati baseret på fordomsfri, kritisk debat. Derfor er det i tilfældet Rusland nødvendigt at sætte sig ud over økonomiske globaliseringsbegreber som deregulering og måle åbenheden alsidigt for at evaluere statens samlede og faktiske globaliseringsstrategi. Et godt afsæt for en sådan holistisk tilgang er Barry Buzan og Gerald Segals (1992) begreb om åbenhed på grund af deres brede operationalisering. Uden at nævne Popper skriver de ud fra samme præmis om pluralistiske politiske systemer og markedsøkonomier som overlegne institutionelle rammer. De har med andre ord "åbenhed" som ideal.

Overordnet opererer de med en sondring mellem ekstern og intern åbenhed, hvor de ved ekstern åbenhed forstår, at grænser kan krydses af varer, penge, personer, informationer, transnationale organisationer og ideer. Ikke total åbenhed, da det ville være ensbetydende med statens forsvinden som enhed, men væsentlig og omfattende åbenhed. Intern åbenhed går ud på, at individer og organsationer kan agere frit og uafhængigt af staten, at information stort set spredes frit eller med andre ord, at staten spiller en regulerende frem for en kontrollerende rolle. Indre og ydre åbenhed er altså to sider af samme sag, der handler om individets og andre aktørers frihed, altså om hvor liberal staten er. Buzan og Segal (1992: 3) tilføjer, at åbenhed herved kan oversættes til "tolerance over for intervention" fra andre aktører end staten og regeringen selv. Prøvestenen på tolerancen er, hvor overilet regeringen handler, når den udnævner nogen eller noget til at udgøre trusler mod den nationale sikkerhed.

Overført på den russiske udvikling siden Gorbatjov og især under Putins to embedsperioder må det som udgangspunkt konstateres, at Rusland generelt er blevet uendelig mere åbent end det sovjetiske samfund. Der er nu fri udrejse og, okay, ikke alle har råd til det, men der er tale om et boom i turisme og private udlandsrejser. ${ }^{8}$ Hertil kommer den anderledes frie udveksling af samfundsforskere, politiske aktivister og alskens specialister. Mediebilledet er blevet anderledes uforudsigeligt, idet forfatningen fra 1993 ophævede censuren (Konstitutsija Rossijskoj Federatsii, paragraf 29, stk. 5). Rusland ligger på top 20-listen over lande med højeste antal registrerede internet-brugere verden over (Skak, 2005). I 2005 var der 23,7 mio. internetbrugere i Rusland svarende til 16,5 pct. af befolkningen (New Media Review, udateret). Modsat lande som Kina praktisererer staten ikke censur af internettet, men nogle forskere ser med bekymring på Kremls alternative metode: propaganda (Marcus, 2004). Som anført er Ruslands importkvote ikke høj, men de markedsøkonomiske reformer og ophævelsen af statens monopol på at bestemme priser og produktion - planøkonomiens kendetegn har forandret grundvilkårene afgørende til fordel for åbenhed. Udenrigspolitisk betyder ophøret af den kolde krig et paradigmeskift i åbenhed, men pluralismen indadtil udnyttes primært af ikke-liberale kræfter (Skak, 1996: 137-191; Trenin og Lo, 2005). Alligevel er Rusland idag helt anderledes på bølgelængde med de 
åbne samfund og deres internationale organisationer: USA, EU, NATO samt Europarådet, som Rusland for tiden er formand for, og som er den mest normative og individorienterede internationale organisation, der findes.

Når alt dette om Ruslands faktiske åbenhed udadtil og indadtil er sagt, må det samtidig understreges, at tendensen især i Putins anden præsidentperiode er en større lukkethed og en mere kontrollerende russisk stat (Åslund, 2005; Smith, 2006). Anders Åslund mener, at lukketheden og selvtilstrækkeligheden har nået et omfang, så den truer Putins greb om magten; samme konklusion drager Ian Bremmer (2005/2006). Tilsvarende kritisk er Andrej Illarionov, der selv tog sin afsked som økonomisk rådgiver for Putin ved årsskiftet 2005/2006 (Illarionov, 2006, 2005). I marts 2006 blev der ligefrem udgivet en halvofficiel amerikansk analyse, der stempler Rusland som autoritært (Russia's Wrong Direction, 2006: 65ff.). De mest omdiskuterede stramninger er:

* NGO-loven af 10.01.2006 (for en sober og grundig analyse, Vasegaard, 2006).

* Guvernører vælges ikke længere direkte; partiløse kan ikke opstille til valg.

* Indgreb over for uafhængige medier og adskillige kritiske journalister.

* Indgreb, der truer konkurrenceaspektet ved præsidentvalg og Duma-valg.

* Indgreb, der delvis renationaliserer råstofproduktionen, herunder arrestationen af "oligarken" Mikhail Khodorkovskij (Balzer, 2005).

* Ny militarisme og udenrigspolitisk overmod (Illarionov, 2006; Fedorov, 2006; jf. Putin, 2006a).

Kun det næstsidste punkt, som direkte angår Ruslands politiske $\emptyset$ konomi, uddybes nedenfor. Forinden vil jeg dog minde om, at den demokratiske fernis efterhånden blev noget tynd under Ruslands forrige præsident, Boris N. Jeltsin, hvor de $\varnothing$ konomiske forhold var langt mere kaotiske og uegnede til at fremelske en deltagelsesorienteret middelklasse (jf. Starovoitova, 1998; McFaul, 1998; Shlapentokh, 1996). Det bør også nævnes, at den britiske analytiker Anatol Lieven (2006), der ellers begejstret har skrevet om Baltikums frigørelse og kritiseret Ruslands krig i Tjetjenien, nu tager til genmæle på Ruslands vegne ved at fremhæve hykleriet og det uholdbare i USA's - især vicepræsident Dick Cheneys og EU's nye kritiske distance til Rusland.

Buzan og Segal (1992) supplerer deres åbenhedstilgang med fire forskellige sagområde-vinkler på åbenhed, henholdsvis økonomisk, politisk, militær og sikkerhedspolitisk åbenhed samt social og kulturel åbenhed, hvor jeg af pladshensyn må prioritere Ruslands økonomiske åbenhed. Jeg ønsker nemlig at opholde mig ved en ekstra, men for mig at se afgørende tværgående institutionel sfære, nemlig den retlige dimension af åbenhed, hvor åbenhed kan operationaliseres som en stat, der bygger på sekulære og seriøse retststatstilstande. ${ }^{9}$ Det afgørende kriterium for åbenhed i retlig henseende udadtil og indadtil er naturligvis statens vilje og evne til at tage vare på ikke-statslige aktørers rettigheder og sikkerhed. Med hensyn til denne overordnede kategori må det siges, at Rusland og sådan set også Sovjetunionen altid har lagt vægt på retlig åbenhed udadtil, dvs. respekt 
for folkeretten (FN-pagten), og bestræbt sig på at overholde sine forpligtelser ud fra den almene folkeretlige norm pacta sunt servanda (dvs. pagter skal overholdes). Problemet har været, at man ofte er gået lige til stregen - nu og da lidt over - i sin fortolkning og implementering af folkerettens normer samt konkrete aftaler (ofte flertydige).

Derfor kan man roligt tage russerne på ordet, når de taler om folkerettens og FN's primat og fremhæver Sikkerhedsrådets ansvar for international fred og sikkerhed. Dels er det et udtryk for reel opbakning til nogle af den internationale politiks få stabilisatorer, dels taler russerne i velforstået egeninteresse, da Rusland selv er Sikkerhedsrådsmedlem (Nikonov, 2006 som citeret ovenfor, jf. Putin, 2006a). Dermed være også sagt, at russerne er selektive og moderne - ikke post-moderne! - med hensyn til, hvilke elementer i folkeretten og international politiks praksis de står vagt om (jf. MacFarlane, 2006: Hurrell, 2006). Det er gerne stormagtsklubber ligesom Sikkerhedsrådets permanente medlemmer (Rusland er åben for en udvidelse af kredsen) og G8, ikke mindst i 2006, hvor Rusland har formandskabet (Putin, 2006b). I det omfang, BRIK-konceptet er gået op for Rusland som stikord for $\emptyset$ konomisk toneangivende stormagter, er det afgjort noget, man bifalder og vil slå storpolitisk og indenrigspolitisk mønt af. Sagt med andre ord er nøglen til for alvor at komme på talefod med Rusland at tænke i det, man inden for teorier om international politik (specielt den engelske skole, se Watson, 1992: 238-250) kalder for koncertmodeller, altså stormagtsklubber med en forpligtelse til at skabe governance og stabilitet og i det mindste undgå storkrige. Denne eksklusive russiske tilbøjelighed kan man selvfølgelig ikke kalde retlig åbenhed i ordets bogstavelige forstand, for hermed er diskussionen ovre i mere pragmatiske institutionelle formler for omverdenens samarbejde med Rusland.

Med hensyn til den retlige åbenhed indadtil har det traditionelt været en akilleshæl, da Sovjetunionen reelt var det modsatte af en retsstat, og fordi det er en lang og sej proces - uanset eventuel politisk vilje fra højeste sted - at skabe retsstatstilstande på alle niveauer og i alle afkroge af den Russiske Føderation (jf. Pedersen, 2001). Da Putin fra januar 2000 overtog tøjlerne efter Jeltsin, erklærede han, at hans politik var "lovens diktatur" (diktatura zakona) og mente det antagelig, blot ud fra den moderne stats kollektivistiske og nationalistiske horisont modsat den post-moderne stats blik for individets og ikke-statslige aktørers rettigheder og behov. Meget sigende har Putin måske fundet sit fyndord hos den berygtede højreekstremist oberst Al'bert Makashov, der i juni 1991 kaldte sig både konservativ og tilhænger af diktatur - lovens og forfatningens diktatur! (Dewhirst, 2005). Putin har imidlertid skarpt kritiseret den vilkårlighed, træghed og korruption, der præger billedet, når lovene føres ud i livet (Putin, 2005) - selv han ser det som et problem, at Rusland fortsat er et ret Kafkask land at leve i. Borgerne i Rusland er ligesom rumænerne storleverandører af sager til den Europæiske Menneskerettighedsdomstol, men deri - altså i Ruslands forpligtende medlemskab af Europarådet kombineret med Ruslands folkeretslovlydighed ligger et potentiale for større åbenhed i retlig henseende. Konklusionen er derfor, at Rusland utvivlsomt har flyttet sig til fordel for retsstaten og retlig åbenhed indadtil siden Sovjet-tiden, men der er lang vej endnu, jf. nedenfor. 
Vedrørende åbenhed $i$ фkonomisk henseende er kriteriet en $\emptyset$ konomi baseret på privat ejendomsret, men Buzan og Segal (1992) tilføjer, at det sagtens kan dreje sig om en blandings $\varnothing$ konomi med flere ejendomsformer og niveauer for privateje. De vil heller ikke på forhånd anse korporatisme for lukkethed, altså kan der være markante forskelle i graden af åbenhed. Ekstern økonomisk åbenhed handler om en stats evne til uhindret at spille sammen med verdens $\varnothing$ konomien, dvs. tilslutning til internationale handels- og toldregimer, fri bevægelighed samt åbenhed over for udenlandske investeringer, hel eller delvis udlandseje osv. Det skal understreges, at de afgørende markeds $\varnothing$ konomiske reformer skete, før Putin kom til, altså under Jeltsin, som sammen med Gorbatjov har æren for opgøret med lukketheden i form af planøkonomi (Pedersen og Skak, 2001). Putin, dvs. hans daværende rådgiver Illarionov bør dog krediteres for i 2001 at have indført en flad skat på 13 pct. for personlig indkomst i stedet for fortidens brandbeskatning, der gav skatteunddragelse og skræmte investorer væk (Bush, 2003). På et enkelt år gav det ifølge samme Jason Bush's data næsten en fordobling af skatteprovenuet til 12 mia.\$. Ruslands aktuelle $\varnothing$ konomiske soliditet skyldes derfor ikke kun de heldige konjunkturer - olieprisernes himmelflugt - omend de er en afgørende faktor.

I det hele taget har der fra forskellige sider været lovord over Ruslands nogenlunde $\varnothing$ konomiske åbenhed, fx hævdede Verdensbanken i 2005, at Rusland var et langt nemmere land at have med at gøre med hensyn til at etablere virksomhed end de andre BRIK-lande. På en liste over 155 lande indtog Rusland 79pladsen, lige over EU-landet Grækenland og over Kina (nr. 91), Indien (nr. 116) samt Brasilien (nr. 119) (Smolchenko, 2005). Rusland roses for at forenkle sine registreringsprocedurer og gøre det let at ansætte folk, følgelig er arbejdsløsheden faldet til et EU-agtigt niveau på 7,7 pct. i snit for første halvdel af 2006 (Vasegaard, 2006). Rusland er dog langt fra en transparent økonomi, for korruptionen er enorm (gælder også andre BRIK-lande), så Ruslands eget erhvervsliv er uenig med Verdensbanken i dens optimisme (Gazeta, 13.09.2005). Samme kilde nævner, at den bestikkelsessum, som embedsmænd typisk forlanger af virksomhederne, er steget 13-fold siden 2001 til gennemsnitligt 135.000\$. Den tendens kan måske tages som udtryk for, at staten jf. "lovens diktatur" mere nidkært forfølger korrupte embedsmænd. Nogle økonomer påtaler, at BRIK-landene har langt højere toldmure end USA og EU, men på det punkt er Rusland nu den mindste synder. Udtrykt med et vægtet gennemsnit for industrivarer, serviceydelser og landbrugsvarer er Rusland omkranset af toldmure på 8,4 pct., hvorimod niveauet for Indien er 21 pct., Kina 12,8 pct. og Brasilien 9,9 pct., mens USA og EU tilsammen ligger på 2,5 pct. (Thagesen og Uldall-Poulsen, 2005).

Sagt med andre ord har Putins bidrag været at konsolidere og udbygge Jeltsins og hans første premierminister Jegor Gajdars reformer - fx på landbrugsområdet (Vasegaard, 2005). Ikke mindst praktiserer Putin og hans ministre selv her under hans anden embedsperiode verbal åbenhed om nogle af Ruslands allermest alvorlige problemer, de reelle trusler mod landets vækst og velfærd, som delvis ville være blevet tiet ihjel i det lukkede sovjetiske samfund. For det første 
eksplosionen i aids-tilfælde - et problem, som truer med at antage sydafrikanske dimensioner: at smitten bevæger sig ud af højrisiko-grupperne og rammer befolkningen som helhed ("Rusland på randen af en aids-katastrofe", 2006). I foråret 2005 kaldte Ruslands myndigheder - under pres fra FN - aids for en trussel mod landets sikkerhed og sænkede drastisk prisen på aidsmedicin (Johnson' Russia List, \#9108, 01.04.2005). Aids raserer i alle BRIK-lande som et problem skabt af globaliseringen, men åbenheden hjælper også den anden vej, i bekæmpelsen af sygdommen, som Brasilien har gode erfaringer med (Johnson' Russia List, \#9108, 01.04.2005; Cardoso, 2004).

For det andet den dramatiske nedgang i befolkningstilvæksten, som truer med at affolke Rusland om ca. 100 år. Således forudser FN's og Ruslands egne prognoser et fald fra de nuværende 146 mio. indbyggere til mellem 80 og 100 mio. pr. 2050; forudsigelser som nogle russiske demografer finder for optimistiske! (Eke, 2006). Derfor var den lurende demografiske katastrofe et hovedtema i Putins seneste tale til Føderationsrådet, hvor han lovede at sætte ind med økonomisk og institutionel støtte for børnefamilier (Putin, 2006a). At Rusland slås med så fundamentale problemer, er noget af det, der gør Rusland til særtilfældet blandt BRIK-landene, som jo ellers er ret konsoliderede og fremadskuende. I sidste instans afspejler Ruslands demografiske deroute forfejlede strategier i landets fortid. Hertil kommer klimaproblemet - dvs. udfordringen, for ikke at sige det antagelig helt håbløse $\mathrm{i}$ at vedligeholde forholdsvis normaløkonomiske tilstande og infrastrukturer - inklusive adskillige millionbyer - i Ruslands arktiske egne; et emne, der blev bragt på bane i en bog med titlen The Siberian Curse (Hill og Gaddy, 2003). Problemstillingen er yderst følsom, da den rummer udsigten til at miste grebet om store dele af territoriet. Derfor erkendes den kun indirekte, men russiske politikere debatterer langtidseffekten af den faktiske åbenhed mellem Kina og Rusland, nemlig kinesiske handlende, der krydser grænsen til Rusland og afhjælper vareforsyningen. Med andre ord ville det være urimeligt at karakterisere Putins ledelsesstil som toned $\varnothing \mathrm{v}$ over for landets faktiske problemer og behovet for åbenhed selv under den seneste tids indiskutable opstramninger.

Men når der ovenfor er brugt udtryk som arrogance og selvtilstrækkelighed, er det fordi den faktiske globaliseringsstrategi, der aftegner sig, rummer store faldgruber med hensyn til evnen til at korrigere fejl og styre fri af korrupte, uduelige magthavere - Poppers (2001) kerneargument for det åbne samfund. Som anført kredser Kremls globaliseringsdiskurs om suverænitet, hvilket i økonomisk praksis udmøntes i et styret marked parallelt med det styrbare/suveræne demokrati (Balzer, 2005; Buckley og Ostrovsky, 2006; Milov, 2006). Det er især Ruslands enorme forekomster og produktion af fossile brændstoffer, der underlægges hel eller delvis statslig styring. Det er en kongstanke hos Putin, som kan føres tilbage til Putins speciale i økonomi fra 1997, som Harley Balzer derfor mener er den egentlige - altså økonomiske snarere end politiske - grund til Khodorskovskij-sagen, der endte med, at staten indirekte, men reelt satte sig på Khodorkovskijs yderst veldrevne olieselskab Jukos' aktiver. Meget sovjetisk/plan$\emptyset$ konomisk og konservativt/stormagtsbevidst har Putin ikke tillid eller tålmodighed til at lade markedets "usynlige hånd" realisere sit politiske program, som 
uden tvivl rummer meget godt for befolkningen: højnede levevilkår, mindre afhængighed af råstofsektoren, russisk konkurrenceevne på verdensmarkedet og sidst, men ikke mindst: omverdenens udelte respekt for Rusland (Putin, 2006a, 2006b).

Faren ved den delvise renationalisering, den statslige bureaukrat-korporatisme, som satte ind for alvor fra 2004 (Milov, 2006), er, at de nye aktører - typisk $\emptyset$ konomisk ubeskrevne blade med en efterretningskarriere eller lignende bag sig (såkaldte siloviki dvs. magtmænd) - som herved rykker ind på ledende poster, får adgang til kolossal rigdom. De kan beslutte skæbnesvangre transaktioner i den russiske og internationale $\emptyset$ konomi, og mønstret breder sig til andre råstofbrancher og våbeneksporten (Buckley og Ostrovsky, 2006; RFE/RL Newsline, 28.06.2006). De statsbureaukratiske korporatistiske aktører risikerer, som de patriotisk-populistiske aktører de også er, at formøble den statslige Stabiliseringsfond, som Rusland (efter norsk forbillede?!) har opbygget. Der er tale om et nyt klimaks i uigennemskuelighed, et tilbageslag for åbenheden. Balzer (2005: 222) sætter trumf på: det specielle ved Ruslands $\emptyset$ konomiske storhed er Ruslands globale betydning som energileverandør. Følgelig er den sande parallel til Ruslands nye opstigning som verdensmagt Spaniens ensidige, dårligt forvaltede guldog sølvbaserede hegemoni i 1500-tallet. Det endte som bekendt med den Spanske "Uovervindelige" Armadas forlis ved Skotlands klippekyster efterfulgt af Spaniens eget storpolitiske forlis. På kort sigt er den nye russiske statskorporatisme og de øvrige mudrede signaler med hensyn til åbenhed utvivlsomt med til at forsinke landets optagelse i WTO, en mærkesag for regeringen, som ellers var berammet til at blive fuldbyrdet ved årsskiftet 2005/2006.

Som afrunding på den statslige russiske globaliseringspraksis følger en "krølle" om Ruslands politik over for udlandseje af virksomheder og udenlandske investeringer baseret på Olsen (2006) og hans kildemateriale. Formelt ligestiller og beskytter investeringsloven fra 1991 udenlandske investorer. Men i praksis er der både uofficielle og officielle barrierer, herunder restriktioner på investeringer i luftfart, naturgas, forsikring, elkraft, rustningsindustri, naturressourcer som resultat af lovændringer i 1999, 2002 og 2003. På den ene side garanteres kompensation for ekspropriation, på den anden side er der i 2005 kommet en gummiparagraf om emner af national sikkerhed primært indført med henblik på naturressourcerne. Problemet er, at Rusland har et skrigende behov for investeringer for at modernisere udvindingen og transporten af fx olie og gas. Der er dog en åbning inden for banksektoren, hvor loftet på 12 pct. andel af udenlandsk kapital blev fjernet i november 2002. Faktisk findes der 100 pct. udlandsejede banker i Rusland. Inden for forsikring er russerne mere forsigtige, men loftet for udlandsandel er hævet til 25 pct., og på det seneste er 50 pct. af forsikringsmarkedet åbent, fx tillades det russiske filialer af forsikringsgiganter fra EU-området at sælge livsforsikringer i Rusland. Til gengæld er der nye opstramninger inden for telekommunikation; noget, der ikke huer WTO. Generelt altså en restriktiv tendens. Alligevel mærkes globaliseringen selv ude $\mathrm{i}$ de russiske lokalsamfund ${ }^{10}$ uanset det russiske civilsamfunds berygtede svaghed (Starovoitova, 1998). 


\section{Konklusion}

Det overordnede indtryk er et Rusland, der fører en noget idiosynkratisk globaliseringspolitik. Man kan godt tale om en overfladisk indlejring af staten i civilsamfundet (Evans, 1997), eftersom Putins popularitet er massiv og navnlig vedvarende og derfor formentlig overgår den opbakning, som er blevet noget andet russisk statsoverhoved til del inklusive Lenin. Men opbakningen handler om lettelse over den stabilitet, der omsider synes at have indfundet sig, ikke om politisk deltagelse. Alligevel skal man ikke underkende langtidseffekten af globaliseringen på menigmand. Internettet og kendskabet til verden udenfor skaber langsomt nye normer og forventninger selv i de fjerneste afkroge af det mægtige russiske rige. En middelklasse vokser frem, og på hjemmemarkedet er der efterhånden et varieret erhvervsliv. Så der er grænser for, hvor pessimistiske konklusioner, der skal drages om forholdet mellem stat og civilsamfund i Rusland.

Hvad angår forholdet mellem stat og marked, altså Ruslands politiske økonomi, er der umiddelbart en smuk overensstemmelse mellem den russiske globaliseringstænkning og statens praksis. Akademikernes globaliseringskritik lægger logisk op til regeringens moderne strategi som svar: at generobre autonomien og kontrollen gennem det suveræne demokrati - læs: konservatisme - og det "styrede marked" - læs: statslig korporatisme. Men alliancen mellem globaliseringsskeptikere på venstre og højre fløj af det politiske spektrum er noget uhellig. Parterne gejler hinanden op i en ørkesløs, modproduktiv jagt på "suverænitet" og trusler mod den - på jagt efter en genre som den litterære modernist Vasilij Aksjonov skrev - alt imens de meget prosaiske, men dødsensalvorlige trusler mod Rusland tårner sig op, samtidig med, at korporatismen gør det sværere at korrigere fejl.

\section{Noter}

1. BRIK = Brasilien, Rusland, Indien og Kina. Artiklen indgår i det forskningsprojekt om BRIK-landene, som jeg leder (Skak, 2005) støttet af henholdsvis Aarhus Universitets Forskningsfond og AU's rammeprojekt Globalisering. Andre projektdeltagere er Steen Fryba Christensen, Aalborg Universitet (Brasilien), Jørgen Dige Pedersen, Institut for Statskundskab, AU (Indien) samt Stig Thøgersen, Institut for Kultur og Områdestudier, AU (Kina). Jeg vil takke mine russiskkyndige studentermedhjælpere, sprogofficererne stud.scient.anth. et oecon. Anne Toft Sørensen (2005), stud.scient.pol. Katrine Vasegaard (2005, 2006) og stud.scient.pol. Lars Skærris Olsen (2006).

2. Jeg er derfor ikke enig med S. Neil MacFarlane (2006: 43-48), når han nærmest gør Gorbatjovs opgør med fortiden til problemet og overser, at hans sovjetiske forgængere er de hovedansvarlige for miseren.

3. Ud over Nikonov (2006) uddyber Rogozjnikov (2005), Tretjakov (2005) - samt anderledes kritisk - Kolesnikov (2005), Novoprudskij (2005) og Yasmann (2006) indholdet i "suverænt demokrati". Man får over 9000 siders tekst, når man googler det på russisk, det er altså særdeles "hot" blandt publicister. Jeg er den danske lektor på Skt. Petersborgs Statsuniversitet, Jelena Krasnova, og studieadjunkt på Slavisk og Ungarsk Afdeling, AU, Galina Starikova, tak skyldig for hjælp med disse henvisninger.

4. Klub-93 blev oprettet i 1993 på initiativ af samme Nikonov. Andre prominente medlemmer er Sergej Karaganov, Andranik Migranjan og Lilija Shevtsova (Klub-93, 2006; 
jf. Skak, 1996: 180). Der er samarbejde og overlapning mellem den logeagtige Klub-93 og tænketanken SVOP (Sovjet Vneshnej i Oboronnoj Politike, Rådet for Udenrigsog Forsvarspolitik), hvis analyser ofte inspirerer Kreml. Nikonov er præsidentrådgiver, men også en synlig politisk aktør (http: //www.polity.ru/nikbio.htm.).

5. Den tidligere Brezjnev-kritiske filosof Aleksandr Zinovjev ("Russia in a Globalizing World", 2001: 55) har et rent konspirationsteoretisk syn på globaliseringen: "an allout total war - planned and constantly waged and conducted in minute detail - by the Western world not simply for world supremacy, but for putting mankind's evolutionary process under its control”. Når globalisering gøres synonymt med amerikanisering, overses det, at Vesten selv vånder sig under outsourcing. Men det er klart, at de på forhånd åbne vestlige samfund har en hjemmebanefordel ved globaliseringen sammenholdt med diverse lukkede samfund, jf. den videre analyse nedenfor.

6. Ja, man fristes til at genoplive den gamle stamokap-teori som redskab til at forstå nutidens Rusland, dvs. teorien om den statslige monopolkapitalisme. Under den kolde krig blev stamokap brugt af Moskva-tro kommunister som karakteristik af de åbne samfund, især USA og dets "syv søstre", der sad på olien og så ud til at styre verdens gang. Men markeds $\emptyset$ konomiens problem med enkeltfirmaers magt, lukkethed og undertrykkelse løses næppe af, at lukketheden overføres til det statsbureaukratiske niveau som i Rusland, tværtimod giver det statslig monopolkapitalisme!

7. Jeg benytter her Gunnar Myrdals (1972) princip om at vedgå sig sine værdipræmisser som nøgle til videnoverførsel inden for samfundsvidenskab.

8. I 1993 rejste 8,5 mio. russiske statsborgere udenlands, ti år efter var tallet steget til 11,4 mio., hvoraf 8 mio. var turister og private besøgende. Af de private rejsende tog over 1 mio. til Tyrkiet, over 650.000 til Kina. Egypten er en anden populær destination ("Russians abroad", udateret; jf. Andreyeva, 2006).

9. Kriteriet om sekulære retstilstande betyder, at fx en stat, der bygger på sharia (islamisk lov) eller anden religiøs lov, ikke kan betragtes som åben. Kriteriet om seriøse retsstatstilstande er med, fordi Sovjetunionen selv midt under 1930'ernes terror og skueprocesser lagde vægt på visse juridiske formalia - Stalin-forfatningen af 1936 gav på papiret en lang række borgerlige rettigheder.

10. Russiske sociologer har fulgt globaliseringens gennemslag i Kostroma-regionen (300 $\mathrm{km}$ nordøst for Moskva). Der får landsbybeboerne filtreret indtryk fra storbylivet i Moskva og Skt. Petersborg gennem slægtninge i hovedbyen Kostroma ("celle-globalisering"). Folk bliver mindre hæmmede og lovlydige, mere individualistiske. Landbrug erstattes af nicheerhverv med sigte på byboernes luksusforbrug (turisme, $\varnothing$ kologiske produkter, jagt- og fisketure; tendenser, der kendes herhjemme). Johnson's Russia List, \# 128, 02.06.2006: \#16: "Event summary: Globalization in the Russian Heartland".

\section{Litteratur}

Andreyeva, Yelena (2006). "Record Number of Russians Spend Winter Abroad", The St. Petersburg Times, 24.01, her fra: http: //www.sptimes.ru/index.php?action_id=2\& story_id=16633.

Balzer, Harley (2005). "The Putin Thesis and Russian Energy Policy", Post-Soviet Affairs, Vol. 21, No. 3, pp. 210-225.

Bremmer, Ian (2005/2006). "Who's in Charge in the Kremlin?", World Policy Journal, Winter, pp. 1-6.

Buckley, Neil and Arkady Ostrovsky (2006). "Back in Business - how Putin's allies are turning Russia into a corporate state", Financial Times, 19.06.

Bush, Jason (2003). "A Flat Tax Is Taking Root in, of All Places, Russia. From each according to ... oh, never mind", 26.05., http: //www.businessweek.com/magazine/ content/03_21/b3834174_mz034.htm 
Buzan, Barry and Gerald Segal (1992). "Introduction: Defining Reform as Openness", pp. 1-17 in Gerald Segal (ed.), Openness and Foreign Policy Reform in Communist States, London and New York: Routledge.

Cardoso, Fernando Henrique (2004). "Learning from Brazil: The Politics of Responding to HIV/AIDS in Brazil, China, and India", The Watson Institute for International Studies, http: //watsoninstitute.org/events_detail.cfm?id=346.

Cooper, Robert (2004). The Breaking of Nations: Order and Chaos in the Twenty-First Century, London: Atlantic Books.

Dewhirst, Martin (2005). "9/5 propaganda opportunity for Putin", Johnson's Russia List, \#9246, item 18, 15.09 .

Eke, Steve (2006). "Russia faces demographic disaster", $B B C$ News, downloaded fra: http: //news.bbc.co.uk/2/hi/europe/5056672.stm.

Evans, Peter (1997). "The Eclipse of the State? Reflections on Stateness in an Era of Globalization", World Politics, Vol. 50, October, pp. 62-87.

Fedorov, Yury E. (2006). "'Boffins' and 'Buffoons': Different Strains of Thought in Russia's Strategic Thinking", Russia and Eurasia Programme, Briefing Paper, REP BP 06/01, March, London: Chatham House.

Friedman, Thomas (2005). The World is Flat. A Brief History of the Globalized World in the Twenty-First Century, London: Allen Lane/Penguin.

Gazeta (2005). "World Bank Exaggerates Russia's Business Rating", 13.09.

Hill, Fiona og Clifford G. Gaddy (2003). The Siberian Curse. How Communist Planners Left Russia Out in the Cold, Washington DC: Brookings Institution Press.

Hirst, Paul and Grahame Thompson (2001). Globalization in Question. The International Economy and the Possibilities of Governance, Cambridge: Polity Press.

http: //www.polity.ru/nikbio.htm (russisk biografi for Vjatjeslav A. Nikonov).

Hurrell, Andrew (2006). "Hegemony, liberalism and global order: what space for wouldbe great powers?", International Affairs, Vol. 82, No. 1, pp. 1-19.

Illarionov, Andrej (2005). "Putin's liberal economic adviser resigns, saying Russia 'not free"”, 27.12, fra http: //www.breitbart.com/news/2005/12/27/051227130907.obcu6uet. html.

Illarionov, Andrej (2006). "Putin's Address Heralds Return to Soviet Times - Illarionov", http: //mosnews.com/commentary/2006/05/12/illarcomment.shtml.

Johnson's Russia List.

Klub-93 (2006). Fra: http: //www.polity.ru/club-93.htm.

Kolesnikov, Andrej (2005). "Suverennaja demokratija protiv demokratii", 22.11. fra: http: //www.gazeta.ru/column/kolesnikov/479381.shtml.

Konstitutsija Rossijskoj Federatsii (1993). Rossijskaja Gazeta, 10.11.

Kosolapov, Nikolaj Alekseevitsj (2005). "Globalizatsija: territorial'no-prostranstvennyj aspekt", Mirovaja Ekonomika i Mezjdunarodnye Otnoschenija, Nr. 6, pp. 3-13.

Larsson, Robert L. (2005). "Russia suffers from globalisation fears", Framsyn, nr. 5/http: //www.foi.se/FOI/templates/Page 4593.aspx.

Lehmbruch, Gerhard and Philip Schmitter (eds.) (1982). Patterns of Corporatist PolicyMaking, London/Beverly Hills, CA: Sage Publications.

Lieven, Anatol (2006). "A hypocritical approach to Russia", Financial Times, 31.05.

MacFarlane, S. Neil (2006). "The 'R' in BRICs: is Russia an emerging power?", International Affairs, Vol. 82, No. 1, pp. 41-57.

Marcus, Alexander (2004). "Internet and Democratization: The Development of Russian Internet Policy", Demokratizatsiya, Fall, 21 p., her fra: http: //www.gradewinner.com/ p/articles/mi_qa3996/is_200410/ai_n9466391\#continue.

McFaul, Michael (1998). "Russia's Summer of Discontent”, Current History, October, pp. 307-312. 
Milov, Vladimir (2006). "The Power of Oil and Energy Insecurity", President of the Institute of Energy Policy, Institute of Energy Policy, Moscow, Russia, January (20 p.).

Mitsek, S. (2002). "Sleduet li Rossii opasat'sja globalizatsii?", Voprosy Ekonomi, Nr. 1, pp. 21-30.

Myrdal, Gunnar (1972). Om verdensfattigdommen, København: Fremad.

New Media Review (udateret). The European Travel Commission, 28.06.06 22.40 fra http: //www.etcnewmedia.com/review/default.asp?/SectionID=11\&CountryID=83.

Nikonov, Vjatjeslav (2006). "Suverennaja demokratija", Trud, 15.04, her fra: http: //www. polity.ru/articles/suvdem.htm.

Novoprudskij, Semjon (2005). "Suverennaja demokratija' - psevdonim diktatury, a 'Jedinaja Rossija' - eto simulakr", http: //osada.sova-center.ru/discussion/4E7886A/5BF7A 4C?print=on (om hans indlæg på http: //www.gazeta.ru/column/novoprudsky/31693 4.shtml; også brugt her).

Olsen, Lars S. (2006). "Om Ruslands politik med hensyn til helt eller delvist udenlandsk ejerskab af virksomheder", upubliceret notat, August (5 p.).

O’Neill, Jim (2001). "Building Better Global Economic BRICs", Global Economics Paper, No. 66, 30.11 .

O’Neill, Jim (2006). "How to Sustain This Better World Economy", Global Markets Daily, Goldman Sachs Global Economic Website, 20.03 (4 p.).

Pedersen, Karin Hilmer (2001). "Rusland og retssamfundet", Politica, 33. årg., nr. 2, pp. 138-151.

Pedersen, Karin Hilmer og Mette Skak (2001). "Rusland mod det tredje årtusinde", Politica, 33. årg., nr. 2, pp. 125-137.

Popper, Karl (2001). Det åbne samfund og dets fjender. I-II. København: Spektrum.

Putin, Vladimir (2005). "Poslanie Federal'nomu Sobraniju Rossijskoj Federatsii", 25.04, Moskva, Kreml', Prezident Rossii, Ofitsial'nyj Sajt.

Putin, Vladimir (2006a). "Poslanie Federal'nomu Sobraniju Rossijskoj Federatsii", 10.05, Moskva, Kreml', Prezident Rossii, Ofitsial'nyj Sajt.

Putin, Vladimir (2006b). Transcript of the Press Conference for the Russian and Foreign Media, January 31, Circular Hall, the Kremlin, downloaded 20.06: http: //www.kremlin.ru/ eng/speeches/2006/01/31/0953_type82915type82917_100901.shtml.

RFE/RL Newsline 28.06.2006, Vol. 10, No. 118, http: //www.rferl.org/newsline/1-rus.asp. Rogozjnikov, Mikhail (2005). "Shto takoe 'suverennaja demokratija",, Ekspert, No. 43 (489) 14.11., her fra http: //www.inop.ru/publication/page78/

Rosenau, James N. (1990). Turbulence in World Politics, New York: Harvester Wheatsheaf. Rozanova, Julia (2003). "Russia in the Context of Globalization", Current Sociology, Vol. 51, No. 6, pp. 649-669.

"Rusland på randen af en aids-katastrofe" (2006). Ritzau, gengivet af MetroXpress, 02.06.

"Russia in a Globalizing World" (2001). International Affairs (Moscow), Vol. 47, No. 3, pp. 47-85.

Russia's Wrong Direction (2006). What the United States Can and Should Do. Report of an Independent Task Force, New York: Council on Foreign Relations, March.

"Russians abroad" (udateret). Fra: http: //www.gbrussia.org.reviews.php?id=124.

Scholte, Jan Aart (2005). Globalization. A Critical Introduction, New York: PalgraveMacmillan.

Shlapentokh, Vladimir (1996). "Early Feudalism - The Best Parallel for Contemporary Russia”, Europe-Asia Studies, Vol. 48, No. 3, pp. 393-411.

Skak, Mette (1993). "Rusland og Europa", Økonomi og Politik, 66. årg., nr. 4, pp. 13-21.

Skak, Mette (1996). From Empire to Anarchy. Postcommunist Foreign Policy and International Relations, London: Hurst \& Co.

Skak, Mette (2005). "BRIK'en i globaliseringsspillet: Brasilien, Rusland, Indien og Kina som globaliseringsomgivelser for Danmark i fremtiden". Projektbeskrivelse til Aarhus Universitets Forskningsfond, September (3 p.). 
Smith, Mark A. (2006). "Russia: Transition to a Medvedev Presidency?", Conflict Studies Research Centre, UK Defence Academy, February (6 p.).

Smolchenko, Anna (2005). "Business is Getting 'Easier, Cheaper"”, Moscow Times, 13.09.

Starovoitova, Galina (1998). "A Democratic House of Cards", Transition, June, pp. 35-37.

Stopford, John og Susan Strange (1991). Rival States. Rival Firms: Competition for World Market Shares, Cambridge: Cambridge University Press.

Surkov, Vladislav (2005a). "Vladislav Surkov's Secret Speech: How Russia Should Fight International Conspiracy", Johnson's Russia List \#9199, 13.07.

Surkov, Vladislav (2005b). "The West Doesn't Have to Love Us", Spiegel interview with Kremlin boss Vladislav Surkov, Der Spiegel, No. 25, 20.06, her fra: http: //service. spiegel.de/cache/international/spiegel/o,1518,druck-361236,00.htm.

Surkov, Vladislav (2006). "Putin Aide Outlines Main Threats to Russia, 04.03 fra: http: / /www.mosnews.com/news/2006/03/04/surkovsays.shtml.

Sørensen, Georg (1998). "Suverænitet og statstyper", pp. 156-165 i Birthe Hansen og Carsten Jensen (red.), Grundbogen $i$ statskundskab, København: Akademisk Forlag.

Thagesen, Peter og Hans Uldall-Poulsen (2005). "Opkomlinge. Turboøkonomierne er ikke længere de rene offerlam", Politiken, 11.12.

Toft Sørensen, Anne (2005). Den russiske globaliseringsdiskurs, Putins taler til den føderale forsamling 2000-2005, samt executive summaries af russiske bidrag til globaliseringsdebatten, altsammen upubliceret.

Trenin, Dmitri (2002). The End of Eurasia. Russia and the Border Between Geopolitics and Globalization, Washington DC and Moscow: Carnegie Endowment for International Peace.

Trenin, Dmitri og Bobo Lo (2005). The Landscape of Russian Foreign Policy DecisionMaking, New York: Carnegie Endowment.

Tretjakov, Vitalij (2005). "Suverennaja demokratija. O polititjeskoj filosofii Vladimira Putina, fra http: //www.archipelag.ru/agenda/povestka/-comment2005-/philosophy/ ?version=forprint.

van Ree, Erik (2002). The Political Thought of Joseph Stalin. A study in twentieth-century revolutionary patriotism, London and New York: RoutledgeCurzon.

Vasegaard, Katrine (2005). "Ruslands magtstatus på tre dimensioner”, upubliceret bacheloropgave, Institut for Statskundskab, Aarhus Universitet, juni, samt fem tidslinjer for reformtiltag på det retlige, $\varnothing$ konomiske, politiske, militære felt samt inden for kultur og kommunikation samt andre upublicerede notater.

Vasegaard, Katrine (2006). NGO-reformen i Rusland, januar 2006, samt Forsvarsministerens tale i Dumaen 15 FEB 2006, Ruslands stabiliseringsfond, alle upublicerede, samt aktuelle arbejdsløshedstal og organisering af stof fra Johnson's Russia List.

Watson, Adam (1992). The Evolution of International Society. A comparative historical analysis, London \& New York: Routledge.

Wilson, Dominic and Roopa Purushothaman (2003). "Dreaming with BRICs: The Path to 2050", Global Economics Paper, No. 99 (udgiver: Goldman Sachs), fra: http: // www.gos.com/insight/research/reports6.html).

Yasmann, Victor (2006). "['Sovereign Democracy: '] Russia: Ideological Doctrine Paves Kremlin's Course", RFE/RL Inc. Her efter Johnson's Russia List, No. 177, \#7.

Åslund, Anders (2005). "Putin's Decline and America's Response", Carnegie Endowment for International Peace, www.CarnegieEndowment.org, August, Policy Brief \#41, her fra Johnson's Russia List \#9220, 09.08.05 (8 p.). 